\title{
“Testing Regionalism, Transnationalism, and the Construction of Brazil: An Interview with Luiz Ruffato"
}

\section{Cecily Raynor}

McGill University

Luiz Ruffato is one of the most prominent writers in contemporary Brazilian literature. Born in 1961 in Cataguases, Minas Gerais, Ruffato recently gained significant exposure through his opening speech at the Frankfurt International Book Fair in October of 2013, the focus of which was on Brazilian literature. Rather than praising his home country, Ruffato spoke at length about the complex socioeconomic challenges facing Brazil, including poverty, lack of access to education, illiteracy, and income inequality. The speech generated a great deal of polemical dialogue in Brazil, on the cusp of two major international events: the 2014 World Cup and the 2016 Summer Olympic Games in Rio. Raised in a lower-middle class family of Italian immigrants (his father was a popcorn vender and his mother a washerwoman), Ruffato has faced many of the hardships he notes in his speech. This experience shapes Ruffato's writings, in which he consistently explores poverty, immigration, and socioeconomic marginalization. A selection of his extensive body of work includes the critically acclaimed, Eles eram muitos cavalos (2001), his five-volume collection Inferno Provisório (2005-2011), and his most recent novel, Flores Artificiais (2014). Ruffato has published numerous short stories, collections of poetry, and essays, and he serves as a prominent public figure in Brazil.

During our meeting, which took place in August of 2013, I spoke with Ruffato about a range of topics, from regionalism to transnationalism, his decision to participate in the Amores Expressos collection and specifically on Estive 
em Lisboa e lembrei de você. Two of his novels will be released as films this year, both Estive em Lisboa e lembrei de você (Dir. José Barahona), as well as Redemoiho (based on the novel, $O$ mundo inimgo, dir. José Luiz Villamarin). Our dialogue included discussions on migration, contemporary literature, language use, and the construction and appropriation of space within the fluid terrain of contemporary Brazil. ${ }^{1}$

Raynor: Firstly, could you introduce yourself and discuss with us how you came to be a writer?

Ruffato: It's a long road. I have a trajectory within Brazilian literature that is very unusual. Here in Brazil, as you may have noticed, there is a huge social gap and all writers, almost without exception, come from a middle-class or upper middle-class background. I come from a place that is not middle-class, or even lower middle-class, it's lower-lower middle-class. My mother was a laundress and my father was popcorn seller. Imagine! This profession has not existed in the United States for centuries, right? My mother was illiterate, as was my father. I worked for a long time as my father's helper, as a popcorn seller and also in a tavern. Later, I worked as a mechanic and then as a laborer in the textile industry. Why am I telling you this? I am telling you this because I was not meant to be a writer. I was meant to be anything but a writer. However, when I was in journalism school, I started reading literature, and more specifically Brazilian literature, with great interest. I was startled because I discovered that the universe that I came from was not portrayed in Brazilian literature. This is because middle-class people create literature in Brazil and are only interested in their universe or the universe of gangsters, but not the universe of workers. So, my decision was a conscious one: I want to write about this universe, because there is nothing written in the current literature that represents this universe. It was a political decision that was very clear to me. If I were to write, I had to write about this universe. So more or less this is my path to becoming a writer.

Raynor: Could you speak to the genre of the novel, in general terms? 
Ruffato: In my opinion, the novel arose from the need to create a worldview on behalf of the bourgeoisie, and therefore of capitalism. Capitalism has undergone some evident changes over time. And to deal with these changes, the novels and its representations have also changed. Thus, it is clear that the twenty-first century novel is not the same novel of the nineteenth or twentieth centuries. This is because nineteenth-century capitalism is different from twentieth- or twentyfirst-century capitalism. So where does Estive em Lisboa e lembrei de você fit into my work at large and what I wanted to achieve? This is a question that I have been asking since the beginning: how do I write about the lower middle class without relying on the bourgeois form of the novel? The bourgeois novel is always related to identity, it seeks to describe an identity in order to describe a biography. And because my protagonists don't necessarily have a biography, as much of Brazil's poor population, I needed to approach this formal question. So, in 2001, I published Eles eram muitos cavalos, which was an attempt to understand part of this formal aspect. Then, throughout the 2000s, I published five volumes of Inferno Provisório, which is also an attempt to construct a collective novel, in the sense that it does not have protagonists, meaning that people as a collective are the primary protagonist. And out of all of this arose Estive em Lisboa. And what is Estive em Lisboa? It was my intention to discuss the broad migrations occurring in Brazil during the second half of the twentieth century. This is what I tried to accomplish with Inferno Provisório, which described the violence inherent in the transformation of the entirety of Brazil over fifty years. For me this illuminates the violence of Brazil today. In the midst of all of this, beyond the internal migrations, there was the 1980s, the so-called lost decade, during which a significant migration abroad occurred. I knew I would have to deal with this matter at some point. This was on my horizon and then I received the proposal to participate in the Amores Expressos project, and I chose Lisbon precisely because I wanted to place this particular issue into question. For me the novel is inserted into the discussion about the broad migrations in Brazil during the fifty years between 1950 and 2000.

Raynor: Estive em Lisboa is written in the form of a testimony. How did Serginho's testimony come to be? Was it a chance meeting in Lisbon or did you already know him? 
Ruffato: This, for me, is the greatest risk the novel takes. I needed to create a false situation, in order to persuade the reader into a false reading of the novel. Serginho does not exist, nor has he ever existed.

Raynor: No? I was convinced!

Ruffato: Great, that was the idea. If I had not put that statement at the beginning of the novel, the story would have existed nonetheless. Now why did I put it there? Precisely to create a sense of ambiguity in relation to the narrative that was being written. It is one thing to write a book under the pretense that Serginho exists and to discuss things happening in his life, etc. It's another matter to read the story knowing that it is fiction. What I did was create an extended joke with the reader and propose to him that what he was reading was not fiction. It was the truth. And as the truth, one undertakes a different type of reading than one might if it were known to be a fiction, though in reality it is fiction. Serginho never existed. That interview never happened. Interestingly, the only thing that was real were the people's names.

Raynor: Oh, the names of the protagonists?

Ruffato: No, the names of the people in the note preceding the text. When I said, "I thank my friend, the engineer X." Or when I thank the journalist Paulo Nogueira; all of these people exist. The café in Lisbon also exists, and the address does as well. When the book came out in Lisbon, some journalists went to the café to talk to Dona Rosa, who is the owner of the restaurant, Solar dos Galegos, and she told them, "Of course I remember perfectly! He sat in that very table." And she gave interviews. And this was great because, I thought, well OK then. So it exists.

Raynor: The myth is there.

Ruffato: The myth is there. Later, I returned one day to have a glass of wine with Dona Rosa, and I said: “Dona Rosa, do you remember me?" And she said, "Of 
course I remember you! I thought it was so cute, you sitting there and talking with him [Serginho]." It's very funny! And once, I remember when I was in San Paulo on a Saturday night, and the phone rang at my house, I answered. On the other end was a person I know in Cataguases, not a friend but a well-known person in the community. So he tells me, "I am here with a guy who wants to talk with you. Talk with him." So I talk with his drunken friend who says, "Is this Luiz Ruffato? The one who wrote that book about Lisbon?" I confirm and he says, "Well, my boy, did you know that Serginho is back in Cataguases?" And I said, "Seriously?" And he said, "It's true. He's back and when you get back here, we are going to take you to have a beer with him."

Raynor: How incredible! I wanted to talk to you a little bit more about migration. In your body of work, this theme comes up frequently, particularly Italian immigration to Brazil. Where does this novel fit within this broader theme?

Ruffato: When considering the last fifty years in Brazil, it was very important for me to think about how people interfere in history and how history interferes in people's lives, because these things are abstract, not concrete. For me, the history of Brazil in the last fifty years is the story of the displaced person. It is a spatial story, a story of space, of the conquering of space and also history changing paradigms across time. You don't just move physically, you also move in time. Time and space are inseparable in physics, so you have to imagine the following. When you have a large transformation from rural space to post-urban space, in a mere fifty years, you also have a change in the quality of time. Time is no longer successive, but rather simultaneous. So it is important to think of how people were or were not prepared for these radical changes in space and time. For me it's important to work with the idea of uprooting. My idea was to focus on a community that had long been migrating, in this case Italians. Italian grandparents had migrated to the interior of Minas Gerais at the end of the 19th century. Then in the 1950s, their children were part of the rural exodus, right? So you already have the problem of leaving the rural lands. You go from wide-open spaces in the country, to small and enclosed spaces in the city. Even here in João Pessoa you have small spaces, and you are 
forced to leave the mythical time of the country, to go to a place where time dominates space and swallows you up. I am interested in these shifts of paradigm. I focused on a community of Italian immigrants in order to understand this microcosm over the last 50 years. There's a song by Caetano Veloso, which sums up my concern. He says, "Here in this country, where what is constructed is already in ruins."

Raynor: Right, the important concept of ruin.

Ruffato: What I have tried to do is precisely to mimic this ruin-the ruin of the disintegration of the family, the ruin of domestic violence-mimic this in the very form of the novel, which is itself a ruin. Even in Estive em Lisboa this idea is present. It is less so than in other works, but it is present. There is a moral collapse at the beginning and the end of the narrative. The novel undergoes a series of interferences, including linguistic interferences in the second part that leave it in a state of ruin. The narrative disintegrates over time.

Raynor: Language is something you frequently experiment with in your work at large, and it continues to play a role in Estive em Lisboa, as you highlight Serginho's language use in an intentional and deliberate way. Can you speak a little bit about this decision? How do you negotiate the question of regionalisms in a novel such as this, especially when we consider the stigma that regionalism has in the history of Brazilian literature?

Ruffato: This is a great question, but the question preceding this one bothers me a great deal. Who defines what is regional and not regional? Hegemonies decide. For example, if I write about Rio de Janeiro it is not regional because the hegemonic culture is located there, as well as in San Paulo. But if I write about Minas Gerais, it is considered regional because it is not hegemonic. Brazil in relationship to the United States is regional because we are not hegemonic in comparison. So there is always this discussion of center and periphery. So, the first question of a regional novel is defining what is regional. Regional literature does not belong to a hegemonic culture, to begin with. So, this is already a debatable matter. What 
defines a regionalism? Is a novel regional because of its language? If it's the language, we return to the idea of cultural hegemony. There is an attempt to make Rio de Janeiro the dialectal hegemon of Brazilian Portuguese, something we see frequently in films. Here in João Pessoa, the female news broadcaster is not from Paraíba, neither ethnically nor linguistically. She is a white woman from the South, who speaks with a carioca [Rio] dialect. The television soap operas also use the standard accent from Rio, and there is undoubtedly an attempt to impose a cultural hegemony from Rio. Everything that is not from Rio or San Paulo is considered to be regional. This has created a number of problems in Brazil, including for Southern writers from Rio Grande do Sul, who do not use the pronoun "tu" because they would be considered regionalists. So, you end up abandoning your own identity in order to not be considered a regionalist. This is a tragedy! What I have attempted to do is to ignore completely this question of whether or not I am a regionalist. Why? Because I refuse to accept this cultural hegemony, and the role of the writer should always be to question cultural hegemonies. And if I simply assume the hegemonic culture, I can no longer question it. The second thing is that I intentionally wrote this novel in "mineirês" [the dialect spoken in Minas Gerais], rather than Portuguese. However, this is an invention, it is an artificial language in the novel. Here I attempted to reproduce the oral character of spoken "Mineirês" within a context that is no longer valued. It was intentional because I wanted to highlight the contrasts of a migrant from Minas Gerais in Lisbon. So I contrasted the language spoken in Brazil with the Portuguese language that is spoken in Portugal, and beyond this, I contrasted this Brazilian Portuguese, because this is not a language spoken in the rest of Brazil. It has a rhythm and a syntax that are completely different than the language you would hear in Paraíba for example. So the idea was to use regionalisms to question what is regional. It would be ridiculous to me for someone to say that the novel is regional, when it takes place in Lisbon. Is it a question of language and not a question of space? It was intentional; that is, this radicalization of one aspect in order to discuss the idea of regionalisms, if they actually exist. For me, this is purely a political question.

Raynor: Could you elaborate a bit on your decision to participate in the Amores Expressos project? 
Ruffato: The original project was based on a Brazilian film production company, RT Features (Rodrigo Teixera Features), which was resurfacing at a particular moment. The production company wanted to create a series of films. The idea was to send writers overseas to different cities across the world, to write love stories in these cities. Why in other cities in the world? It was easier to create film production agreements in the United States, France, etc. than to do it alone. In the beginning the idea was purely commercial and not intended for literature, but for film. The second step was that Companhia das Letras was interested in making a deal to publish the best books of the collection, not all, but the ones they found interesting. The project went from having a purely commercial interest to having a literary one. So what was my intention in all of this? Firstly, I have to pay my bills and they paid very well. Secondly, they said I could choose the city I wanted to travel to. Because if they had told me I needed to live in for example, New Delhi, I would not have accepted. That is because I would be faking my literary interest. Given my interest in working on Brazilian immigration abroad, I had three or four options. One was Japan, when considering the decasséguis [Japanese migrants working abroad, here to Brazil]. But Japan didn't exist within the imaginary of my city, Cataguases. In other words, I didn't know anyone who left Cataguases to go to Japan. The other great option was the United States, but there was already someone going to New York. So then I considered Europe, including Italy. But there were not many people going to Italy and I didn't want to get involved in the world that involved primarily transvestites and prostitutes, similar to Spain. The place that was strongest in the migration of the Brazilian working-class was Portugal, and I had no doubts about Lisbon. So then I accepted the project, and I knew from that moment that I was not going to write a love story.

Raynor: But there is a love story in the novel, right?

Ruffato: I think so. When I turned the book in to the editor he said, "Wait, only half of this takes place in Lisbon! The book is already short, and half occurs in Cataguases and half in Lisbon. And there is no love story!" And I said, "It does take place in Lisbon, you never said the whole thing had to take place in 
Lisbon. And it does have a love story." To which he said, "What love story?" And I told him, "You have to look for it!" So, the basic idea in accepting the project was money-I have no problem writing under contract-and because I was interest in the question of Brazilian migration abroad.

Raynor: What type of role do you think the Amores Expressos project has within Brazilian literature more broadly?

Ruffato: All of the writers undertook the projects in their own ways. I don't think the project itself is important for Brazilian literature. I think the results of some of the books may or not be important for the body of work of specific writers, but the project itself cannot be evaluated from this point of view, especially because it is so broad, and has a diverse set of authors and projects. I would not look at it as a totality. Some books are still being released and I think it will be easier to see the project in its totality later on. Though, honestly I don't think it will make much of a difference. I don't think you will be able to look at it as a literary project within Brazilian literature.

Raynor: Returning to the structure of the novel, it is divided between Cataguases and Lisbon, making the idea of space essential. What role does space play across the novel?

Ruffato: I enjoy reflecting on the concept of space in my work, not only in this novel. I like to think about how we appropriate space in Brazil. From an outsider's perspective, Brazil is situated in a dichotomy. On the one hand, it is depicted as extremely lyrical and romantic, and also the opposite. But the truth lies in between; it is neither one thing nor the other. If you consider a place like São Paulo in the 1950s, it had about a million people and today it has nine million within the city's limits and almost twenty million in Greater São Paulo. So how do we deal with space in urban areas? We deal with it poorly, because in Brazil we have a very strange concept: that which does not belong to a single person belongs to no one. This is a strange idea, because in the US it is the opposite. In the US, that which belongs to no one belongs to everyone. If you think about this concept, you 
come to understand Brazil in general and why we have such an issue with public littering, loitering, etc. This is because the only space that matters is my space, not our space. This also explains violence in Brazil. I protect my own home but the moment I go out into the streets, I can drive my car over everyone out there. So the public space is one of confrontation, and the private space is one of domestic violence. The public space is one of confrontation in all ways imaginable; political confrontation, politicians can steal public goods because the public doesn't belong to anyone. Historically, we arrived in Brazil relatively recently, we have an amalgamation of immigrants, and we've always been beaten down. Because we've always been beaten down, we beat down others around us. In Brazil, savage capitalism is not a metaphor, it's the truth. We are savage! This is why Brazil is frequently seen as a romantic place from abroad, because it is savage!

Raynor: Right, I see. Importantly, Estive em Lisboa is framed in such a way that Serginho quits smoking in the first half and then takes it up again at the end of the second half. What motivated this decision?

Ruffato: I needed a method of marking time and the turn the tale makes in Serginho's spatial route. I needed markers that were psychological, which was when he quit smoking and when he started again. But these had to be markers of survival and necessity. Quitting in the first half is a metaphor for leaving something that brings him a lot of pleasure, Brazil. For all of its bad points, it's his country. Then quitting smoking becomes quitting something that gives him pleasure. Even if it's a toxic pleasure. Brazil is a toxic pleasure! It is pleasurable, the best place in the world to live, but it kills you. And the second half was exactly the opposite, he is detoxing but he isn't happy because he has no pleasure. So the decision to start smoking again at the end of the novel is indicative of his decision to return to Brazil. It's not explicit, but we see him returning to something that gives him pleasure. Smoking is something that is registered in your memory as pleasurable, but as something that is going to kill you.

Raynor: The second half of the text is very rich in memory sequences. What role does memory play within the novel and in migration more generally? 
Ruffato: That is also an important issue because when Italian immigrants came to Brazil they were not only poor, they were miserable. Taking this status and thinking about Brazilian migration in general, what is the great tragedy of migration? It is not losing your food, which is important. It is not losing your language, which is also very important. All of these points are related to culture in general and have to do with breaking away from your history. In Western civilization, where is the connection to memory? It is in the cemetery. Eastern civilization has other traditions, but we have our cemeteries. And when you migrate you cannot take your cemeteries with you. When you migrate, you break with your past and you have to start anew. And so for me, that was a thing that made me uncomfortable. It has to do with the appropriation of space. Why do we sense that public spaces don't belong to anyone? Because we are constantly inaugurating history, regardless of where you go in Brazil, you are unlikely to find people who have four generations of people in a cemetery. It's very hard to find this. What does this mean? It means that we do not appropriate ourselves to our own space; this space is not mine. So for me it was very important to comprehend that memory and a lack of memory determine the construction of society.

Raynor: Immigration is frequently depicted in Brazilian literature, both historically and in contemporary literature. Why do you think literature is a particularly effective medium to tell migrant tales? What does it facilitate that other arts do not?

Ruffato: One thing special about literature is that it supersedes the other arts not because it is better or worse, but because of the way the human mind thinks. We envision our lives in words. We don't think in images, but in words, making literature different than cinema for telling stories. So literature ends up being a repository for the most important thing in Western culture, which is memory, right? It serves as a type of repository for the questioning and selfreflection of our own language, offering up a series of possibilities that other arts do as well, but only precariously. What is interesting is that it is also the most elitist art, because it requires knowledge that is not required of cinema, visual arts, and music. 
Raynor: Finally, I'd like to talk to you about the idea of a transnational literary aesthetic in contemporary Brazilian and Hispanic literature. Do you think this type of aesthetic may be emerging when we consider the spaces that are being treated in literature today, such as extra-national literature? Do you think that the Amores Expressos project might be part of a larger tendency?

Ruffato: Yes, I do think that we can see such a tendency. Now, I even think you can identify when this happened. This happened for two reasons: first, it involves the projection of Brazil abroad in the last ten years or so. I'm referring to the Brazilian economy, the Brazilian political landscape, and in the world broadly. Brazil has gained a visibility it did not have previously. Of course this affects the imaginary of Brazilian authors who are also citizens of the world; they can speak about any place in the world, not specifically Brazil. This is a concrete and fortuitous fact motivated by macro-level forces. But there is also a micro-level question, which is also artificial but that has repercussions: the increased interest that the National Library has in giving translation grants for Brazilian literature. This ends up generating curiosity and foreign publisher interest in Brazilian literature. Literary agents arrive in Brazil and say: "Look, I'm interested in buying Brazilian books, but I'd like to buy something that extends a bit beyond Brazil." Then authors start publishing and writing a different type of literature to meet this demand. So what I want to say is that there are two aspects that are transnational. One of them is absolutely legitimate, real and concrete, which is that our literature feels comfortable discussing broader issues extending beyond Brazil. American literature has done this too, as seen in the case of Hemingway in the Spanish Civil War. And then there is the other issue, which is that Brazilian literature itself is being guided by external demand. So, it's like Brazilian cinema today, which thinks like this: "I will made this film to please a studio in Hollywood so that the next film I make can be produced in Hollywood and not in Brazil." In other words, you are meeting an internal need in order to attend to an external need. So there are two impetuses that are very clear to me, and they both have the same beginning. First, Brazil has started to gain visibility, and second, this expanded when the National Library started to give out scholarships for translations. 
Raynor: Thinking a little bit more about transnationalism, do you agree that it will become more difficult to speak about national literatures in the future? Such as Brazilian literature, Argentine literature and Chilean literature. Do you think this tendency towards transnationalism will grow? If you have a text that has no Brazilian protagonists but takes place in Russia, is this Brazilian literature because of the writer's nationality?

Ruffato: I want to start with this last statement, because I think it determines the first. What determines whether literature is Chilean and not Argentine or Brazilian is the register of the author. As much as I might want to write American literature, I will never be able to. First, because I do not write in English and second, because my worldview is completely contaminated by the environment in which I live. I could even start writing in English tomorrow, but it is not my maternal language, and thus I will never have the same expressiveness in this language. But we are talking about a worldview. Language determines one's worldview. So much so that we say there are no pure translations and that translation is always a betrayal. If true translation were possible, you could mirror the text onto another. However, you cannot translate the worldview; you can translate the expressions, but not the worldview. So what determines the nationality of a piece of writing is the language it was written in because it brings with it a specific worldview. You can say: "I am Russian, my story takes place in Russia, but I am writing in Portuguese and am a Brazilian author, so the literature is Brazilian and not Russian."

Raynor: These are difficult questions, right? If you have Brazilian parents and you spent your entire life in Spain and you write about Brazil, is it Brazilian literature or Spanish?

Ruffato: If you are writing in Spanish and you spent your entire life in Spain, you can write about Brazil, but the literature you write will be Spanish.

Raynor: If you spent half your life in Brazil? 
Ruffato: Of course, these are generalizations and everything has its limits. But I think in general, what determines this is the place from which you are writing, which determines your register. Let's take Junot Diaz, for example. He is not a Dominican writer. People refer to him as a "Dominican writer." He was born in the Dominican Republic, that's why. But he writes in English. And he writes from the point of view of an American. He does not write as a Dominican would, he writes as an American, and thus he writes American literature, not Dominican. The best example you could give me would be Puerto-Rican literature. Because Puerto Rico obviously has its own culture but it belongs to the United States. But if you ask a Puerto Rican what he is, he will say he is a Puerto Rican. He will have a Puerto Rican worldview and not an American one. It is becoming more and more possible for literature to test the boundaries of national space, but this does not change its essence. Its essence will always be located in the place the author grew up. Literature may become more and more migratory, but the essence is always there.

Raynor: Thank you for your time; it's been a pleasure.

Ruffato: The pleasure was all mine. 


\section{Note}

1 This interview was made possibly through the Brazilian Fulbright Commission, in bilateral collaboration with the US Department of State.

Cecily Raynor is Assistant Professor of Latin

American Studies at McGill University. She received her doctorate from Georgetown University.

Her research focuses on contemporary Latin

American literature, transnationalism and the

digital humanities. She has published on spatial

representations in contemporary Brazilian literature in the journal Estudos de Literatura Brasileira Contemporânea. Her current book project explores the representation of a postnational aesthetic in a series of contemporary Latin American narratives. 